\title{
THYROID HYPOFUNCTION IN MALE PARTNERS ATTENDING INFERTILITY CLINIC AND ITS IMPACT ON SEMEN PARAMETERS
}

\author{
K. Neelaveni' ${ }^{1}$ Padmaja Divakar², Rakesh Kumar Sahay³
}

${ }_{1}^{1}$ Associate Professor, Department of Endocrinology, Osmania Medical College, Hyderabad, Telangana.

${ }^{2}$ ART Specialist, Dr. Padmaja Fertility Centre, Hyderabad, Telangana.

${ }^{3}$ Professor and HOD, Department of Endocrinology, Osmania Medical College, Hyderabad, Telangana.

ABSTRACT
BACKGROUND
Thyroid disorders are common in females and their impact on the female reproduction is well established. The role of thyroid
hormone on male reproduction received much attention with recognition of thyroid hormone receptor expression on gonadal cells.
Studies in humans evaluating the impact of varying severity of thyroid hypofunction on male fertility are limited.

\section{OBJECTIVE}

To study the thyroid status and correlation with semen parameters in male partners of couples attending infertility clinic.

\section{MATERIALS AND METHODS}

In this retrospective study, data on thyroid hormone levels, anti-TPO antibodies, semen parameters of 125 men attending infertility clinic, after excluding men with known thyroid disorder, on thyroid medication, other drugs and medical conditions which have an influence on thyroid status, were analysed.

\section{RESULTS}

Of the total 125 subjects, $84 \%$ men were euthyroid, whereas thyroid hypofunction, which included subclinical hypothyroidism and overt hypothyroidism was observed in $14.4 \%$ and $1.6 \%$ of men respectively. $11 \%$ of the subjects had positive anti-TPO antibodies. Normal semen parameters were observed in 82 subjects whereas 43 men had abnormal semen parameters. None of the semen parameters correlated with TSH; however, there was a non-significant increase in spermatozoa with abnormal morphology ( $95 \%$ vs. 90.8\%, p=0.522), decrease in spermatozoa with normal morphology (5\% vs. 7.38, $\mathrm{p}=0.273$ ) and decrease in sperm count (49.24 vs. 37.67 million $/ \mathrm{mL}, \mathrm{p}=0.473$ ) in subjects with $\mathrm{TSH}>10$ in comparison with subjects with $\mathrm{TSH}<10$.

\section{CONCLUSION}

This study found higher prevalence of thyroid hypofunction, and higher positive TPO antibody status among men attending infertility clinic. No correlation was found between thyroid hormones and semen parameters.

\section{KEYWORDS}

Thyroid, Hypofunction, Semen, Infertility, Thyroid Deficiency, Male Reproduction.

HOW TO CITE THIS ARTICLE: Neelaveni K, Divakar P, Sahay RK. Thyroid hypofunction in male partners attending infertility clinic and its impact on semen parameters. J. Evolution Med. Dent. Sci. 2016;5(79):5870-5873, DOI: 10.14260/jemds/2016/1324

\section{BACKGROUND}

The impact of thyroid dysfunction on female reproduction has been clearly established. With regard to male reproduction, though few earlier studies were controversial, in the past two decades, the role of thyroid hormones in male reproduction received much attention with identification of thyroid hormone receptors and their expression at different stages of development of germ cells. $(1,2,3,4)$ Animal studies found the effect of hypothyroidism on immature, and mature testis was different, $(5,6,7)$ and also reversal of sperm fertility characteristics with T4 administration.(8) Human studies also found the differential effect of hypothyroidism, depending on whether it occurred prepubertally or postpubertally. $(9,10,11)$

Financial or Other, Competing Interest: None.

Submission 10-09-2016, Peer Review 20-09-2016,

Acceptance 26-09-2016, Published 01-10-2016.

Corresponding Author:

K. Neelaveni,

Department of Endocrinology,

Osmania Medical College,

Hyderabad.

E-mail: neelaveni1@yahoo.co.in

DOI: $10.14260 /$ jemds/2016/1324

(c) $(1)$
Short-term hypothyroidism has no impact whereas prolonged hypothyroidism may have an impact on male reproduction in adults.(12) Studies on the impact of hypothyroidism on spermatogenesis and semen parameters are contrast and limited. Hence, an attempt has been made to study the prevalence of thyroid hypofunction and relationship with semen parameters in male partners of couples attending infertility clinic.

\section{MATERIALS AND METHODS}

This retrospective study reviewed the medical records of a total of 342 male partners of couples attending infertility clinic of tertiary care teaching hospital between Jan 2016 to May 2016. Data on thyroid hormones and semen analysis was available for 167 men. Out of which, data on 125 men analysed in the present study, remaining 42 men's data excluded. Exclusion criteria included subjects with pre-existing thyroid disease, prior vasectomy, varicocoele, cryptorchidism, hyperprolactinaemia, on thyroid medication, steroids, chemotherapy and drugs which can affect thyroid hormone status like amiodarone and lithium. Recorded data on TSH, anti-TPO antibody status, semen parameters were analysed, to know the relationship between thyroid status and semen 
parameters. Based on TSH levels, study subjects were categorised into euthyroid (TSH $<5 \mu \mathrm{IU} / \mathrm{mL}$, normal free T4), subclinical hypothyroid (TSH $>5.0 \mu \mathrm{IU} / \mathrm{mL}$, normal free T4) and overt hypothyroid (TSH $>10$, low free T4). Subjects were categorised into euthyroid group $(\mathrm{TSH}<5)$ and thyroid hypofunction group (TSH $>5$ ), and were compared. To know the impact of severity of thyroid hypofunction, subjects were categorised, with $\mathrm{TSH}<10$ and $>10$, and were compared for semen parameters. Normal semen analysis ${ }^{(13)}$ was considered when 1 . Semen volume $\geq 1.5 \mathrm{~mL} ; 2$. Sperm concentration $\geq 15$ million/mL; 3 . Sperm count $\geq 39$ million per ejaculate; 4 . Total sperm motility $\geq 40 \%$ (progressive sperm motility $>32 \%$ ); 5 . Spermatozoa with normal morphology $\geq 4 \%$. Based on this, subjects were classified into having normal semen or abnormal semen parameters. Institutional ethical committee clearance was taken to analyse the data.

\section{STATISTICAL ANALYSIS}

R Programming software (Version 3.0) was used for data analysis. Results were expressed as Mean \pm SD. Differences between means were analysed by student's unpaired $t$ test using two tailed tests for significance. $\mathrm{P}=<0.05$ was considered statistically significant. Analysis of the correlation between parameters was performed by using Pearson's bivariate correlation coefficient.

\section{RESULTS}

The age of subjects ranged from 27-54 with a mean age of $34.14 \pm 36.23$ years, and with mean BMI of $26.39 \pm 6.99 \mathrm{~kg} / \mathrm{m}^{2}$. Of the total subjects, $84 \%$ of the subjects $(n=105)$ were euthyroid, whereas $14.4 \%(n=18), 1.6 \%(n=2)$ were having subclinical hypothyroidism and overt hypothyroidism respectively as shown in fig-1. Positive anti-TPO antibodies were observed in $11 \%$ of subjects, shown in fig- 2 . Semen parameters were not significantly different in euthyroid and thyroid hypofunction group as shown in table-1, .There was a non-significant increase in spermatozoa with abnormal morphology $(95 \%$ vs. $90.78 \%, p=0.522)$, decrease in spermatozoa with normal morphology $(5.0 \%$ vs. $7.38 \%$, $\mathrm{p}=0.273$ ), and decrease in sperm count (37.67 vs. 49.24 million $/ \mathrm{mL}, \mathrm{p}=0.473$ ) in subjects with $\mathrm{TSH}>10$ in comparison with subjects with TSH $<10$, as shown in table- 2 .

$65.6 \%(n=82)$ of the subjects had normal semen parameters, whereas $33.6 \%(n=43)$ had abnormal semen parameters. TSH and free T4 levels were not significantly different in subjects having normal and abnormal semen parameters, whereas anti-TPO antibody positivity was higher in subjects with abnormal semen than normal group, similarly smokers were more in subjects with abnormal semen, as shown in table-3. No correlation was found between Semen parameters (semen volume, count, motility and morphology) and TSH as shown in table-4.

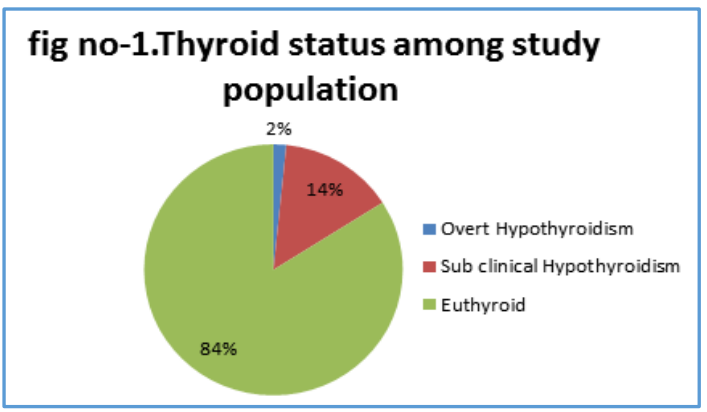

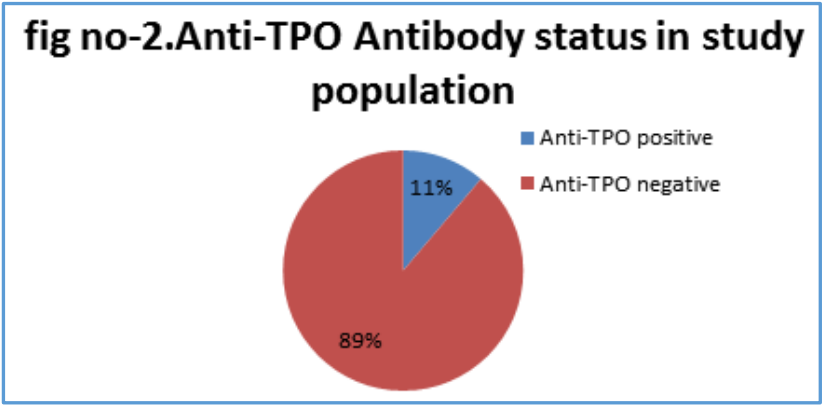

\begin{tabular}{|c|c|c|c|}
\hline Parameter & $\begin{array}{l}\text { Euthyroid } \\
\text { Group } \\
\text { (TSH <5) } \\
\text { n=105, }\end{array}$ & $\begin{array}{c}\text { Thyroid } \\
\text { Hypo } \\
\text { Function } \\
\text { Group } \\
\text { (TSH>5) } \\
\text { n=20, } \\
\text { (Mean } \pm \text { SD) }\end{array}$ & $\begin{array}{c}\text { p- } \\
\text { value }\end{array}$ \\
\hline $\begin{array}{l}\text { Age (years) } \\
\text { (Mean } \pm \text { SD) }\end{array}$ & $34.02 \pm 5.86$ & $34.80 \pm 5.40$ & 0.581 \\
\hline $\begin{array}{c}\text { BMI }\left(\mathrm{kg} / \mathrm{m}^{2}\right) \\
(\text { Mean } \pm \text { SD) }\end{array}$ & $26.70 \pm 7.45$ & $24.63 \pm 3.00$ & 0.236 \\
\hline $\begin{array}{l}\mathrm{TSH}(\mu \mathrm{IU} / \mathrm{mL}) \\
(\text { Mean } \pm \text { SD })\end{array}$ & $2.19 \pm 0.94$ & $11.49 \pm 13.52$ & $<0.001$ \\
\hline $\begin{array}{c}\text { Free T4 } \\
(\mathrm{ng} / \mathrm{dL}) \\
(\mathrm{Mean} \pm \mathrm{SD})\end{array}$ & $1.24 \pm 0.186$ & $1.303 \pm 0.173$ & 0.04 \\
\hline $\begin{array}{c}\text { Anti-TPO } \\
\text { Antibody } \\
\text { Positivity }\{\mathrm{n}, \\
(\%)\}\end{array}$ & $5(4.76 \%)$ & $9(45 \%)$ & - \\
\hline $\begin{array}{c}\text { Semen Volume } \\
(\mathrm{mL}) \\
(\mathrm{Mean} \pm \mathrm{SD})\end{array}$ & $2.56 \pm 1.27$ & $2.44 \pm 0.73$ & 0.703 \\
\hline $\begin{array}{l}\text { Sperm count } \\
\text { (millions } / \mathrm{mL} \text { ) } \\
(\text { Mean } \pm \text { SD) }\end{array}$ & $47.47 \pm 26.19$ & $57.59 \pm 33.51$ & 0.161 \\
\hline $\begin{array}{l}\text { Total Motility } \\
(\%)(\text { Mean } \pm \text { SD) }\end{array}$ & $57.03 \pm 15.35$ & $58.06 \pm 12.26$ & 0.794 \\
\hline $\begin{array}{c}\text { Normal } \\
\text { Morphology } \\
(\%)(\text { Mean } \pm \text { SD) }\end{array}$ & $7.21 \pm 3.71$ & $7.88 \pm 3.62$ & 0.493 \\
\hline \multicolumn{4}{|c|}{$\begin{array}{c}\text { Table 1: Semen Parameters in Euthyroid and Thyroid } \\
\text { Hypofunction Group }\end{array}$} \\
\hline
\end{tabular}

\begin{tabular}{|c|c|c|c|}
\hline Parameter & $\begin{array}{c}\text { TSH }<\mathbf{1 0} \\
\mathbf{n}=121 \\
(\mathbf{m e a n} \pm \text { SD) }\end{array}$ & $\begin{array}{c}\text { TSH }>\mathbf{1 0} \\
\mathbf{n = 4} \\
(\mathbf{m e a n} \pm \text { SD) }\end{array}$ & $\begin{array}{c}\mathbf{p}- \\
\text { value }\end{array}$ \\
\hline $\begin{array}{c}\text { Semen volume } \\
(\mathrm{mL})\end{array}$ & $2.54 \pm 1.22$ & $2.62 \pm 0.63$ & 0.887 \\
\hline $\begin{array}{c}\text { Sperm count } \\
\text { (millions/mL) }\end{array}$ & $49.24 \pm 27.72$ & $37.67 \pm 8.74$ & 0.473 \\
\hline Total Motility (\%) & $57.06 \pm 15.06$ & $61.67 \pm 2.89$ & 0.599 \\
\hline $\begin{array}{c}\text { Spermatozoa with } \\
\text { normal } \\
\text { morphology (\%) }\end{array}$ & $7.38 \pm 3.69$ & $5.00 \pm 3.00$ & 0.273 \\
\hline $\begin{array}{c}\text { Spermatozoa with } \\
\text { abnormal } \\
\text { morphology (\%) }\end{array}$ & $90.78 \pm 11.34$ & $95.00 \pm 3.00$ & 0.522 \\
\hline \multicolumn{3}{|c|}{ Table 2: Comparison of Semen Parameters in } \\
Subjects with TSH $>\mathbf{1 0}$ and $<\mathbf{1 0}$
\end{tabular}




\begin{tabular}{|c|c|c|c|}
\hline Parameter & $\begin{array}{c}\text { Normal } \\
\text { Semen n=82 }\end{array}$ & $\begin{array}{c}\text { Abnormal } \\
\text { Semen } \\
\mathbf{n = 4 3}\end{array}$ & $\begin{array}{c}\text { P } \\
\text { value }\end{array}$ \\
\hline Free $\mathrm{T} 4(\mathrm{ng} / \mathrm{dL})$ & $1.30 \pm 0.17$ & $1.25 \pm 0.19$ & 0.04 \\
\hline $\mathrm{TSH}(\mu \mathrm{IU} / \mathrm{mL})$ & $3.59 \pm 6.81$ & $3.55 \pm 5.67$ & 0.979 \\
\hline $\begin{array}{c}\text { Anti-TPO } \\
\text { positive }\{\mathrm{n},(\%)\}\end{array}$ & $4(3.2 \%)$ & $10(8 \%)$ & - \\
\hline Smoking $\{\mathrm{n},(\%)\}$ & $8(6.4 \%)$ & $11(8.8 \%)$ & - \\
\hline \multicolumn{3}{|c|}{ Table 3: Thyroid Status in subjects with Normal and } \\
Abnormal Semen \\
\hline
\end{tabular}

\begin{tabular}{|c|c|}
\hline Semen Parameter & TSH \\
\hline Semen volume & $\mathrm{r}=-0.0559, \mathrm{p}=0.538$ \\
\hline Sperm count & $\mathrm{r}=-0.004, \mathrm{p}=0.962$ \\
\hline Total Motility & $\mathrm{r}=0.0607, \mathrm{p}=0.519$ \\
\hline Sperm Morphology & $\mathrm{r}=-0.0154, \mathrm{p}=0.869$ \\
\hline Table 4: Correlation of TSH with Semen Parameters \\
\hline
\end{tabular}

\section{DISCUSSION}

Thyroid disorders are less common in males. The prevalence of hypothyroidism in males in India found to be $5.02 \%$ and prevalence of undetected hypothyroidism was $3.47 \%{ }^{(14)}$ AntiTPO antibody positivity in males, in India, reported to be $16.8 \% .^{(14)}$

In the present study, $84 \%$ of the subjects were euthyroid, whereas $14.4 \%$ and $1.6 \%$ of the subjects were having subclinical and overt hypothyroidism respectively. TPO antibody positivity was observed in $11 \%$ of the subjects.

The published literature in humans reporting the effect of hypothyroidism on semen parameters is limited and contrasting and mostly from western countries. In this study, we found no significant difference in semen parameters in euthyroid males and males having thyroid hypofunction. Similarly, in the Indian context, Manojkumar Sharma et al(15) found no correlation between thyroid hormones and semen parameters. However, earlier studies by Corrales Hernandez et al(16) found hypothyroidism had an adverse impact on sperm quality and progressive motility, and Jayakumar et al(17) reported some improvement in sperm count and motility with levothyroxine treatment.

Morphological abnormalities of sperm with deformed heads greatly reduces its potential to fertilise the mature oocyte. Thyroid hormones does exert their effect on cell cytoskeleton.(18)

Krassas GE et al(19) in their prospective controlled study found, morphology is the only sperm parameter, significantly differed in hypothyroid patients in comparison with controls, which improved significantly after treatment. Sperm motility also decreased which improved after treatment, but the difference is not statistically significant. In this study, there was a trend towards having lower counts, reduced normal morphology spermatozoa and increased abnormal spermatozoa in overt hypothyroidism than in subclinical hypothyroidism.

Meeker JD et al(20) found an association between free T4 and reduced odds of having sperm motility of less than $50 \%$. We did not find any difference in motility among euthyroid and males with thyroid hypofunction and no correlation with free T4.

Trummer et al(21) found that presence of abnormal thyroid functions were similar in subjects with normozoospermia and pathozoospermia, whereas prevalence of positive TPO antibodies was higher in subjects with pathozoospermia, asthenozoospermia in comparison with normozoospermia. In our study, we found higher antibody positivity in males with abnormal semen. In contrast, Poppe $\mathrm{K}$ et al found(22) prevalence of abnormal thyroid function and thyroid autoimmunity was not different among men with normal and abnormal semen parameters. Limitation of the study is, thyroid status is based on single TSH value, and single measurement of semen sample, whose reproducibility and variability could not be assessed in view of the retrospective type of the study.

In conclusion, this study found higher prevalence of thyroid hypofunction, and higher positive TPO antibody status among men attending infertility clinic. No correlation was found between thyroid hormones and semen parameters.

More research is needed with large prospective studies evaluating the role of thyroid hypofunction on semen parameters and fertility and if found, response to levothyroxine therapy needs to be evaluated.

\section{ACKNOWLEDGEMENT}

We sincerely thank Dr J J Babu, scientist E and Dr. Raja Sriswan Mamidi, scientist B from National Institute of Nutrition (NIN), ICMR, Hyderabad for their wholehearted help and support in preparing the manuscript.

\section{REFERENCES}

1. Hardy MP, Sharma RS, Arambepola NK, et al. Increased proliferation of Leydig cells induced by neonatal hypothyroidism in the rat. J Androl 1996;17(3):231-8.

2. Jana NR, Bhattacharya S. Binding of thyroid hormone to goat testicular Leydig cell induces the generation of a proteinaceous factor which stimulates androgen release. J Endocrinol1994;143(3):549-56.

3. Jannini EA, Crescenzi A, Rucci N, et al. Ontogenetic pattern of thyroid hormone receptor expression in the human testis. J Clin Endocrinol Metab 2000;85(9):3453-7.

4. Buzzard JJ, Morrison JR, O'Bryan MK, et al. Developmental expression of thyroid hormone receptors in the rat testis. Biol Reprod 2000;62(3):664-9.

5. Chandrasekhar Y, Holland MK, D'Occhio MJ, et al. Spermatogenesis, seminal characteristics and reproductive hormone levels in mature rams with induced hypothyroidism and hyperthyroidism. J Endocrinol 1985;105(1):39-46.

6. Hardy MP, Kirby JD, Hess RA, et al. Leydig cells increase their numbers but decline in steroidogenic function in the adult rat after neonatal hypothyroidism. Endocrinology 1993;132(6):2417-20.

7. Weiss SR, Burns JM. The effect of acute treatment with two goitrogens on plasma thyroid hormones, testosterone and testicular morphology in adult male rats. Comp Biochem Physiol A Comp Physiol 1988;90(3):44952.

8. Jiang JY, Umezu M, Sato E. Characteristics of infertility and the improvement of fertility by thyroxine treatment in adult male hypothyroid rdw rats. Biol Reprod 2000;63(6):1637-41.

9. De la Balze FA, Arrillaga F, Mancini RE, et al. Male hypogonadism in hypothyroidism: a study of six cases. J Clin Endocrinol Metab 1962;22:212-22. 
10. Boyages SC, Halpern JP. Endemic cretinism: toward a unifying hypothesis. Thyroid 1993;3(1):59-69.

11. Laron Z, Karp M, Dolberg L. Juvenile hypothyroidism with testicular enlargement. Acta Paed Scand 1970;59(3): 317-22.

12. Krassas GE, Pontikides N. Male reproductive function in relation with thyroid alterations. Best Pract Res Clin Endocrinol Metab 2004;18(2):183-95.

13. World Health Organization. WHO laboratory manual for the examination and processing of human semen-Fifth edition. 2010; P. 225.

14. Unnikrishnan AG, Kalra S, Sahay RK, et al. Prevalence of hypothyroidism in adults: an epidemiological study in eight cities of India. Indian J Endocrinol Metab 2013;17(4):647-52.

15. Sharma MK, Parchwani D, Maheria P, et al. Relationship between thyroid profile and semen quality. National Journal of Community Medicine 2012;3(1):20-24.

16. Hernández CJJ, Miralles MJM, Diez GLC. Primary hypothyroidism and human spermatogenesis. Arch Androl 1990;25(1):21-7. doi: $10.3109 / 01485019008987590$.
17. Kumar JB, Khurana ML, Ammini AC, et al. Reproductive endocrine functions in men with primary hypothyroidism: effect of thyroxine replacement. Horm Res 1990;34(5-6):215-8.

18. Zamoner A, Barreto KP, Filho DW, et al. Propylthiouracilinduced congenital hypothyroidism upregulates vimentin phosphorylation and depletes antioxidant defenses in immature rat testis. J Mol Endocrinol 2008;40(3):125-35.

19. Krassas GE, Papadopoulou F, Tziomalos K, et al. Hypothyroidism has an adverse effect on human spermatogenesis: a prospective, controlled study. Thyroid 2008;18(12):1255-59.

20. Meeker JD, Godfrey-Bailey L, Hauser R. Relationships between serum hormone levels and semen quality among men from an infertility clinic. J Androl 2007;28(3):397406.

21. Trummer H, Ramschak-Schwarzer S, Haas J, et al. Thyroid hormones and thyroid antibodies in infertile males. Fertil Steril 2001;76(2):254-7.

22. Poppe $\mathrm{K}$, Glinoer $\mathrm{D}$, Tournaye $\mathrm{H}$, et al. Is systematic screening for thyroid disorders indicated in sub fertile men? Eur J Endocrinol 2006;154(3):363-6. 